\title{
К ВОПРОСУ О ПРОЕКТНОЙ ДЕЯТЕЛЬНОСТИ В МУЗЫКАЛЬНЫХ УЧРЕЖДЕНИЯХ
}

\section{Федяева Анна Андреевна}

ГБОУДОГС «Севастопольская музыкальная школа №6»

магистрант

РАНХиГС

\begin{abstract}
Аннотация: В данной статье раматриваются важные проблемы в системе детского музыкального образования в Российской Федерации и возможные пути решения их. Важное внимание уделяется проектной деятельности в детских музыкальных учреждениях; еe основам и особенностям.
\end{abstract}

Ключевые слова: музыкальное образование, проектная деятельность, педагогика, проблемы, образовательная деятельность.

\section{ON THE QUESTION OF PROJECT ACTIVITIES IN MUSICAL INSTITUTIONS}

Fedyaeva Anna Andreevna

\begin{abstract}
This article discusses important problems in the system of children's music education in the Russian Federation and possible ways to solve them. Much attention is paid to project activities in children's musical institutions; its foundations and features.

Key words: music education, project activities, pedagogy, problems, educational activities.

Музыкальное образование - неотъемлемая часть формирования человека как гармонично развитой личности. Кроме того, музыка выполняет важную роль в процессе становления и развития мировой культуры. На сегодняшний день музыкальное искусство - это один из главных инструментов идентификации той или иной мировой культуры. Именно через музыкальное образование человек способен познать особенности национальной культуры и формирует представление о национальных культурах других стран мира.
\end{abstract}




\section{ПЕДАГОГИКА И СОВРЕМЕННОЕ ОБРАЗОВАНИЕ:

К сожалению, как и в любой сфере деятельности, в системе музыкального образования имеются свои проблемы и недостатки, которые необходимо устранять. Несмотря на широкую просветительскую деятельность и поддержку со стороны властей, часть острых проблем остается нерешенной. Необходимые радикальные реформы по изменению модели управления учреждениями детского музыкального образования (Детские музыкальные школы (ДМШ) и Детские школы искусств (ДШИ)) требуют больших ресурсных затрат для их реализации. Несмотря на широкую базу нормативноправовых актов, регулирующих сферу детского музыкального образования, она не получает должного развития. Педагог вынужден уделять большое количество времени на ведение документации (отчёты, журналы, индивидуальные планы и прочее).

В Приказе Министерства культуры Российской Федерации от 02.06.2021 № 754 "Об утверждении Порядка осуществления образовательной деятельности образовательными организациями дополнительного образования детей со специальными наименованиями "детская школа искусств", "детская музыкальная школа", "детская хоровая школа", "детская художественная школа", "детская хореографическая школа", "детская театральная школа", "детская цирковая школа", "детская школа художественных ремесел" утверждены направления и особенности процесса обучения в данных учреждениях. Дополнительные профессиональные программы должны быть направлены на воспитание и развитие у учащегося личностных качеств; умение принимать, понимать и уважать духовные ценности разных культур; формирование навыков самостоятельной оценки культурных ценностей; развитие творческих навыков. Фактически, на эти задачи у педагога остается крайне мало времени. В вышеупомянутом Приказе Министерства культуры РФ закрепляется максимальная нагрузка на ученика в период обучения. Продолжительность одного учебного занятия равна академическому часу (составляет 40-45 минут). Объем максимальной аудиторной нагрузки по всем предметам вместе не должен превышать 14 часов для предпрофессиональных программ и не более 10 часов для общеразвивающих программ. Такие строгие рамки и сроки образовательных программ не позволяют учитывать индивидуальные особенности ребенка. Вместо воспитания в ученике любви к музыке, педагог ДМШ или ДШИ вынужден «гнаться» за программными требованиями и технической стороной исполнения музыкальных произведений. Разумеется, такое обучение 
сказывается на желании ребенка познавать сферу искусства, гармоничном и грамотном развитии его музыкальных способностей и на уровне образования в целом. Острой проблемой остается неслаженное взаимодействие между ДМШ и общеобразовательными школами. Одной из основных причин является нахождение этих типов образовательных учреждений под юрисдикцией разных министерств (Министерства культуры и Министерства просвещения соответственно). В наши дни всё чаще возникают вопросы качества образования и спроса, кадрового резерва, условий труда. Как эффективно решить данные проблемы?

Анализ международной практики; принципов функционирования системы детского музыкального образования в зарубежных странах показывает нам об активной проектной деятельности в данной сфере. Что же такое проектная деятельность? Это деятельность, направленная на достижение, поставленной заранее цели, путем создания уникального продукта или услуги. Таким образом, если нашей целью будет являться, например, вопрос спроса на детское музыкальное образование, мы должны создать уникальный продукт (услугу, мероприятие и т.п.), результаты которого способствуют достижению этой цели.

В международной практике подобная деятельность активно поддерживается Международным обществом по музыкальному образованию - International Society for Music Education (ISME). На данный момент ISME активно поддерживает международные проекты по продвижению музыкального образования. Основной задачей этих проектов является улучшение доступа к высококачественному музыкальному образованию для малоимущих групп во всем мире 5 . Среди наиболее масштабных проектов последнего десятилетия, получивших финансовую поддержку ISME стали: проект «Эвтерпа: греческие песни для школ» (Euterpe: Greek songs for schools) в 2012 году; проект африканского музыкального образования (African Music Education Project) в 2013 году; проектное предложение по развитию музыкального образования в Бразилии с 2014 года.

С 2017 года в России наиболее активно стала развиваться проектная деятельность во всех сферах благодаря созданию Фонда президентских грантов. У организаций некоммерческого сектора появилась возможность получать поддержку не только от частных, заинтересованных лиц, но и

${ }^{5}$ International Society for Music Education // URL: https://www.isme.org/ (дата обращения 10.01.2022) 


\section{ПЕДАГОГИКА И СОВРЕМЕННОЕ ОБРАЗОВАНИЕ:

субсидии из федерального бюджета. Сфера культуры и музыкального образования не стала исключением. Более того, в июне 2021 года был дан старт приему заявок на получение грантов от Фонда культурных инициатив (в рамках организации Фонда президентских грантов).

Ежегодно среди заявок на получение грантов подается множество креативных и уникальных проектов, которые направлены на определенные цели и задачи, способны решить ту или иную проблему в определенной сфере деятельности и удовлетворить запросы общества.

Безусловно, большая поддержка практически всем сферам деятельности оказывается благодаря национальным проектам. Однако, она имеет ограничения и может затянуться в сроках реализации. Например, в сфере культуры, закупка новых музыкальных инструментов для музыкальных учреждений может длиться годами (процесс оформления документации, доставка инструментов, трудоёмкий процесс «доказывания» руководителя учреждения необходимости этих инструментов), что оказывает существенное влияние на ход учебного процесса.

Среди проектов в сфере культуры и музыкального образования довольно много направлены на просветительскую деятельность (проведение музыкальных конкурсов, фестивалей, концертов).

Проведя аналитический обзор проблем детского музыкального образования в России, мы пришли к выводу, что необходимо развивать проектную деятельность, направленную на взаимодействие общеобразовательных школ и ДМШ. Следует опираться не только на просветительскую деятельность, но и на сам процесс вовлечения детей и их родителей в сферу профессионального музыкального образования.

Кто должен заниматься проектной деятельностью в ДМШ и ДШИ? В некоторых регионах на данный момент складывается установка, что проектной деятельностью должны заниматься сами педагоги музыкальных учреждений. Эта установка неверна и может привести к негативным последствиям. Помимо профессиональных знаний и навыков проектная деятельность требует большого внимания, ресурсов и времени. Если возложить на педагога (особенно, не владеющего навыками проектной деятельности) подобные дополнительные обязательства, качество и эффективность учебного процесса значительно снизится. Стоит помнить, что преподаватель, в первую очередь, должен заниматься педагогической 
деятельностью. Попытка преуспеть одновременно во всех видах деятельности не приведет к успеху ни в одном направлении.

Безусловно, мнения и пожелания педагогов и руководителей ДМШ и ДШИ должны учитываться при проектной деятельности. Однако самим процессом создания уникального продукта или услуги должен заниматься знающий человек, который не нарушит образовательный процесс музыкального учреждения.

\section{Список литературы}

1. Приказ Министерства культуры Российской Федерации от 02.06.2021 № 754 «Об утверждении Порядка осуществления образовательной деятельности образовательными организациями дополнительного образования детей со специальными наименованиями "детская школа искусств", "детская музыкальная школа", "детская хоровая школа", "детская художественная школа", "детская хореографическая школа", "детская театральная школа", "детская цирковая школа", "детская школа художественных ремесел"»

2. International Society for Music Education // URL: https://www.isme.org/ (дата обращения 10.01.2022)

3. Альтман Г.С. Музыкальное образование за рубежом: к проблеме этнопедагогических основ музыкального образования / Г.С. Альтман // Педагогика. Вопросы теории и практики. - 2017. - №4(8). - С. 7-10.

(C) А.А. Федяева, 2022 